NOTES AND NEW TECHNIQUES

\title{
MULTICOLORED BISMUTH-BEARING TOURMALINE FROM LUNDAZI, ZAMBIA
}

By Mary L. Johnson, Cheryl Y. Wentzell, and Shane Elen

Tourmalines from an alluvial deposit near Lundazi in Zambia consist of color zoned pink/colorless/yellow-green "watermelon” nodules; many fashioned stones contain patches and blends of all three colors. Although these elbaite tourmalines are unusually rich in bismuth (up to 0.49 wt.\% $\mathrm{Bi}_{2} \mathrm{O}_{3}$ ), the presence of bismuth apparently has no effect on their gemological properties. Approximately 10,000 carats of fashioned stones are known to have been produced from October 1996 to mid-1997.

At the 1997 Tucson show, one of the authors (CYW) saw some unusual tourmalines that were reportedly from recent workings in Zambia. Marc Sarosi Co., of Los Angeles, was marketing this material as "mixed-color" tourmaline: Colors available include light-to-medium-toned desaturated pink, orange, green, and yellowish green (see, e.g., figure 1), as well as colorless, and individual fashioned stones frequently contain regions of two or more of these colors. Coincidentally, we found that the chemistry of these tourmalines was unusual, with elevated contents of bismuth (Bi). The purpose

ABOUT THE AUTHORS

Dr. Johnson is manager of Research and Development, and Ms. Wentzell is staff gemologist, at the GIA Gem Trade Laboratory, Carlsbad, Califomia. Mr. Elen is a research gemologist in GIA Research, Carlsbad.

Please see acknowledgments at end of article.

Gems \& Gemology, Vol. 33, No. 3, pp. 204-211.

(C) 1997 Gemological Insitute of America of this article is to report on this new deposit and to document the unusual composition and other properties of this Bi-bearing elbaite.

\section{LOCATION AND ACCESS}

The multicolored tourmalines described in this report were found in a field in the Kalungabeba area of the Lundazi district (figure 2), about $16 \mathrm{~km}$ (10 miles) southwest of Lundazi itself, according to Mr. Sarosi, who visited the site in early 1997. The stones were originally discovered by a person who was digging a hole for an outhouse.

A rough dirt road leads to this site from Lundazi; it is best traveled by four-wheel-drive vehicle. During the rainy season, from about late December until March, the area is often inaccessible.

\section{GEOLOGY}

The geologic feature known as the Mozambique Belt forms a triangular area bounded by the Luangwa valley (eastern Zambia), the Zambezi valley (in northern Mozambique), and Lake Malawi (in Malawi; again, see figure 2). The main rock units in the belt are high-grade gneisses and granitic rocks of 


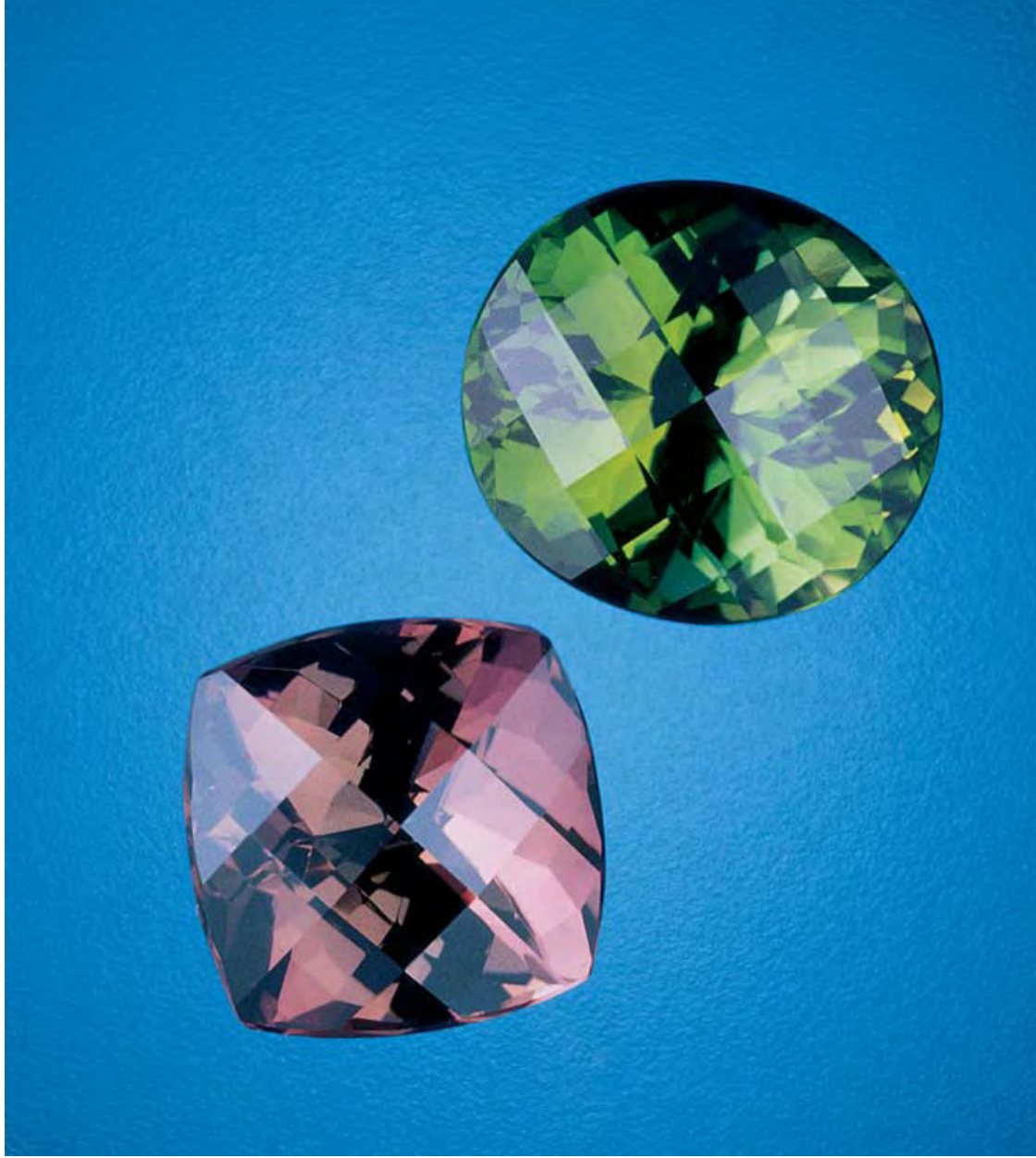

Figure 1. This 9.44 ct pink elbaite tourmaline and its 11.48 ct yellow-green companion are among the thousands of carats of gem tourmaline that have been fashioned from material recovered recently from a deposit near Lundazi, Zambia. Note the distinctive "checkerboard" cut. Courtesy of Marc Sarosi; photo $\mathbb{C}$ GIA and Tino Hammid.

the 2.05-2.68 billion-year-old Basement Complex, as well as metacarbonates, schists, metavolcanics, and quartzites of the 1.35-2.05 billion-year-old Muva Supergroup (Kamona, 1994). The gneisses and schists are intruded by later granitic pegmatites, which commonly have quartz cores and outer zones of microcline feldspars. Muscovite is usually concentrated at the contact between these zones, and aquamarine may occur in either zone. The pegmatites may also contain gem tourmaline, as well as concentrations of rare elements $(\mathrm{Nb}, \mathrm{Ta}, \mathrm{Li}, \mathrm{Cs}$, Y, La, and U). The Mozambique Belt also hosts gold mineralization, in sheared quartz veins occurring in schists and metavolcanics of the Muva supergroup; bismuth minerals (bismuthinite, bismutite) are found in this gold ore.

Tourmaline has been mined in at least three areas in eastern Zambia (figure 2): Lundazi, at the northeast end of the Belt (e.g., the Aries deposit: Kamona, 1994); Chipata, in the center of the belt (see, e.g., Schmetzer and Bank, 1984a and b); and Nyimba, in the south (e.g., the Hofmeyer deposit: Kamona, 1994). The Chipata area is known to produce "intense" yellow tourmalines, (Schmetzer and Bank, 1984a and b; Koivula, 1985); red to brownish red tourmalines (Koivula and Fryer, 1985); and brownish orange and brownish green stones (mentioned by Koivula and Kammerling, 1991). The Hofmeyer pegmatite near Nyimba is the source of tourmaline varieties rubellite and green "emeraldolite" (Kamona, 1994). Bank (1982) described yellowgreen, green, red, brown, and violet tourmalines from Zambia, but he provided no specific information about their source. The bicolored tourmaline mentioned by Thomas (1982) may have come from Lundazi or Nyimba.

\section{MINING AND PRODUCTION}

The Kalungabeba deposit is alluvial, and the tourmaline-bearing gravels also contain spessartine, aquamarine, and dispersed quartz. Both pink and "multicolored" tourmalines have been found, the former occurring in a variety of crystal shapes, but the latter always as nodules; all show wear from alluvial transport. At the time of Mr. Sarosi's visit, there were no known gem-bearing outcrops in the immediate vicinity of this field, although Mr. Sarosi reports that subsequent mining has unearthed spessartine garnet-bearing pegmatites.

Production at this locality started in October 1996. At the time of Mr. Sarosi's visit in early 1997, about $90 \%$ of the tourmaline was coming from a 


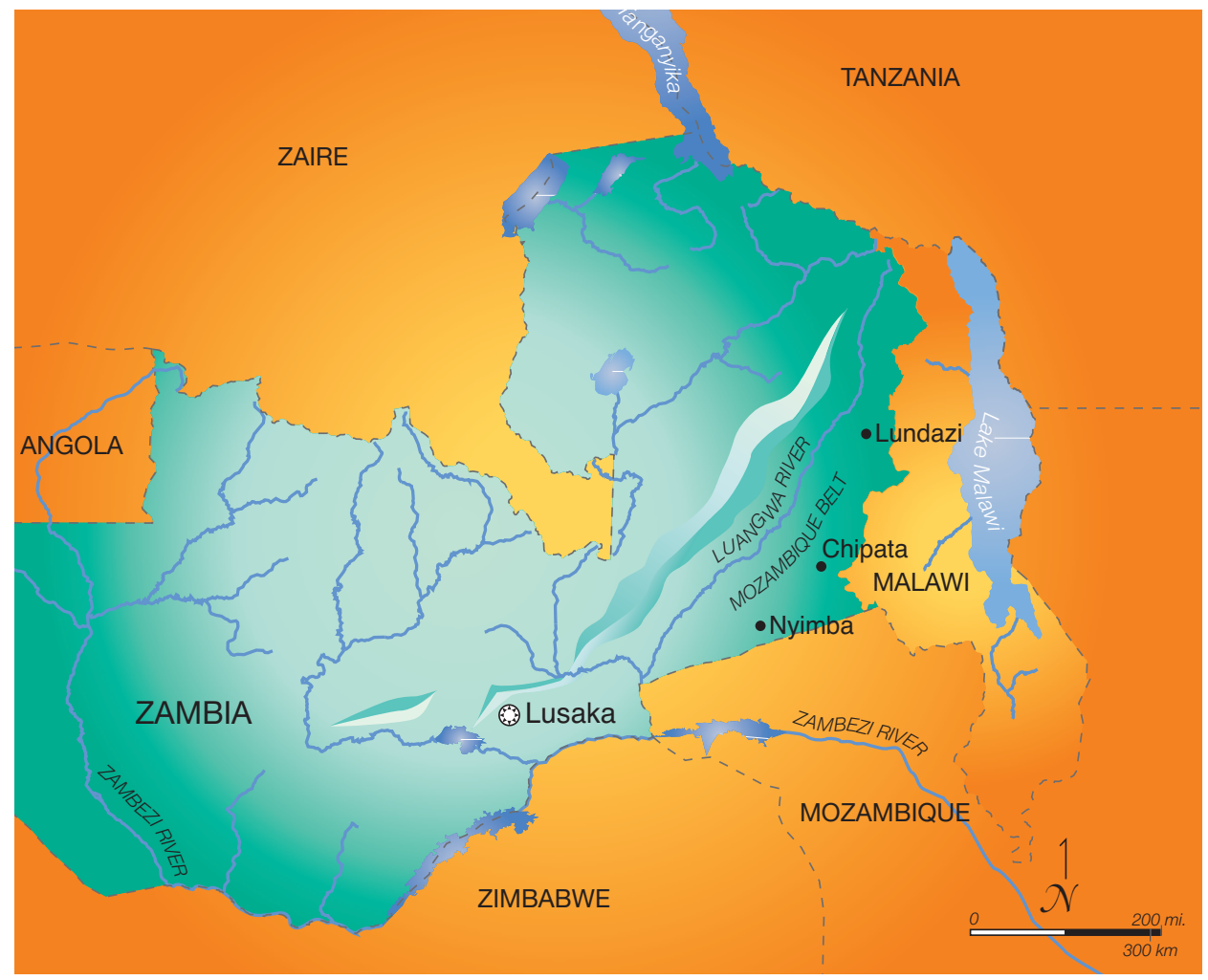

Figure 2. A new deposit of multicolored tourmalines has been found in a field in the Kalungabeba area of Zambia's Lundazi district, about $16 \mathrm{~km}$ southwest of the city of Lundazi.

single pit measuring about $12 \mathrm{~m}$ (40 feet) in diameter and $6 \mathrm{~m}$ (20 feet) deep. Approximately 700 unlicensed miners worked the deposit during the initial "rush"; after five died, the Ministry of Mines closed the area and then issued a number of licenses (around May 1997). At present, approximately 60 miners are working the deposit by hand, hauling loads of gravel to an adjacent water-filled depression, where wet-sieving is done to recover the gem rough. About $100 \mathrm{~kg}$ of facet-quality rough (and several tons of lower-quality material) had been recovered as of June 1997. By this time, Mr. Sarosi, who believes he purchased most of the available multicolored rough, had fashioned some 10,000 carats of goods, ranging up to $20 \mathrm{ct}$.

\section{MATERIALS AND METHODS}

Nineteen faceted stones (3.04 to $11.48 \mathrm{ct}$ ) and 10 nodules $(10.28 \mathrm{ct}[9 \times 11 \times 14 \mathrm{~mm}]$ to $20.61 \mathrm{ct}[12 \times$ $14 \times 15 \mathrm{~mm}$ ]) were examined; these were chosen to represent the variety of material on hand. The faceted stones consisted of six pink, five yellowgreen, and eight multicolored samples; the rough nodules were all multicolored green and pink. We looked at the rough samples with diffuse transmitted illumination to characterize the color zoning, but we did not test these further gemologically.

Gemological characterization of the fashioned samples was performed as follows on all 19 faceted stones, except where noted. We observed the faceup colors using daylight-equivalent fluorescent light sources. Polarization behavior was noted using a GIA GEM Instruments Illuminator polariscope, and we determined pleochroism using a dichroscope and the polariscope light source. The colors seen with a "Chelsea" filter were noted for 13 of the 19 faceted stones, and we measured refractive indices for these same 13 stones using a Duplex II refractometer with a sodium-equivalent light source and a polarizing eyepiece. Specific gravities were determined by hydrostatic weighing (13 stones). Fluorescence was observed in a darkened room using a controlled viewing environment and a GIA GEM shortwave/long-wave ultraviolet lamp. Absorption spectra were noted with a Beck spectroscope in a deskmodel configuration and transmitted light. Microscopic properties were observed with a gemological microscope (Reichert Stereo Star Zoom) equipped with polarizing plates.

We investigated trace-element chemistry by qualitative energy-dispersive X-ray fluorescence (EDXRF) spectroscopy, using a Tracor Xray (now 
Spectrace Instruments) Spectrace 5000 instrument with a rhodium-target X-ray tube. Complete spectra were acquired for six faceted stones, including a bicolored stone for which both pink and green regions were analyzed. It is unusual to see bismuth in tourmaline (Paraíba stones being a notable exception; see, e.g., Fritsch et al., 1990), and we were quite surprised to see evident Bi peaks in the EDXRF spectra of the first stones we examined. Therefore, for eight other stones, data were collected only in the bismuth region $(8-18 \mathrm{keV})$ of the EDXRF spectrum.

Electron microprobe analyses were obtained and processed at the University of Manitoba, Canada, for three samples (3 points each on a $9.44 \mathrm{ct}$ pink cut stone and an $11.48 \mathrm{ct}$ yellow-green cut stone, and 8 points in a traverse along a polished slice from a multicolored nodule). The following elements were quantitatively measured: $\mathrm{Na}, \mathrm{Mg}$, $\mathrm{Al}, \mathrm{Si}, \mathrm{P}, \mathrm{F}, \mathrm{K}, \mathrm{Ca}, \mathrm{Ti}, \mathrm{V}, \mathrm{Cr}, \mathrm{Mn}, \mathrm{Fe}, \mathrm{Zn}$, and $\mathrm{Bi}$ $\left(\mathrm{Bi}_{2} \mathrm{Se}_{3}\right.$ was used as a $\mathrm{Bi}$ standard for analyses, and the detection limit was $0.17 \mathrm{wt} . \% \mathrm{Bi}_{2} \mathrm{O}_{3}$ ). The analytical conditions and methods for calculating the tourmaline formulas are given in Burns et al. (1994).

\section{APPEARANCE AND GEMOLOGICAL PROPERTIES}

Visual Appearance. Rough Material. The nine rough samples (some of which are illustrated in figure 3) seemed typical for tourmaline, showing three-sided symmetry in cross-section. The rounded top and bottom surfaces showed conchoidal fracture, creating an overall nodular shape. Some parallel striations were evident on the sides of the nodules, which is also typical for tourmaline; however, all samples showed worn surfaces.

With diffuse transmitted light, we saw that the rough was zoned "watermelon" fashion, typically with pink triangular cores and green rinds that approached hexagons in outline. Paler (green to colorless) zones were sometimes evident between the pink cores and green rinds (again, see figure 3).

Cut Stones. We examined one round, one cushion, two rectangular, four square, and 11 oval cut stones, all modified brilliants (see, e.g., figure 4). All of the fashioned stones had been modified so that the crown area was covered with many facets ("checkerboard" cut). The colors of these samples are summarized in table 1 . Color distribution ranged from even through uneven to multicolored. Most of the multicolored stones were fashioned to

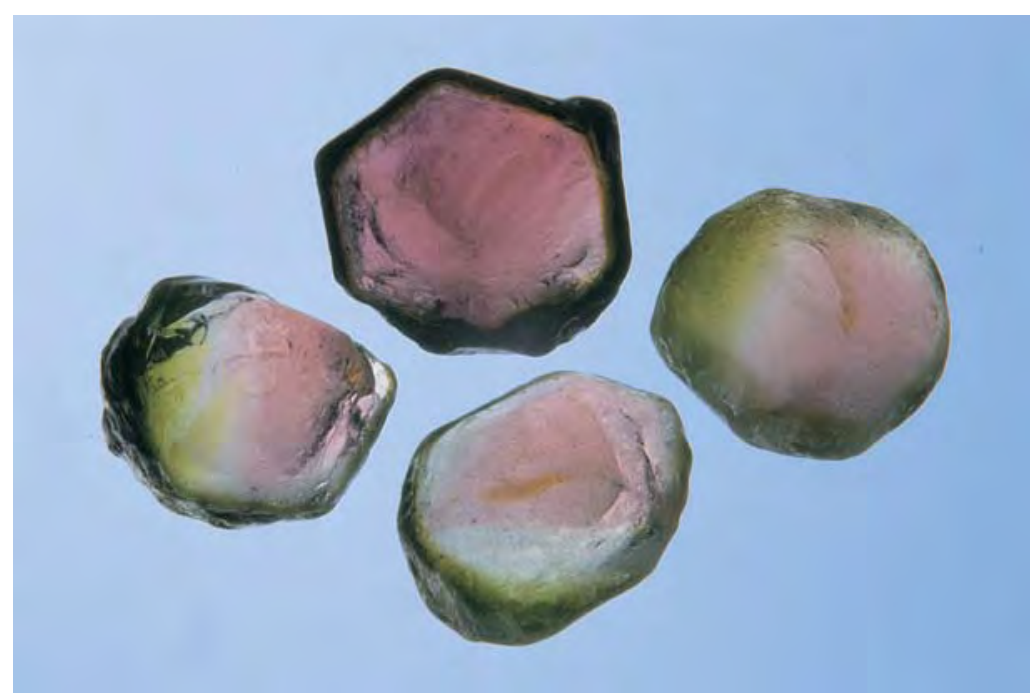

Figure 3. These four tourmaline nodules from the new Lundazi deposit show "watermelon" color zoning. Total weight is $55.73 \mathrm{ct}$, with the largest stone measuring about $15 \times 14 \times 12 \mathrm{~mm}$. Courtesy of Marc Sarosi; photo by Maha DeMaggio.

show patches of color throughout (figure 5), rather than the regular bars of color that are commonly seen in a bicolored or tricolored tourmaline.

According to Mr. Sarosi, this "mixed-color" tourmaline presents some unusual challenges to the gem cutter. To obtain the desired multicolored appearance, Mr. Sarosi noted, the green rind on the rough must be retained in the faceted stone. In addition, the rind also seems to impart physical stability to the stone; if all of it is removed, the stone often breaks during fashioning. Regardless, the tourmaline rough cracks into pieces if sawn. A larger than expected number of stones break during faceting, and a few have even broken after cutting was completed. Because of this, the largest fashioned stones have only reached $20 \mathrm{ct}$ in size, and the rough has a yield of about $20 \%$ (in comparison to an expected yield of $30 \%-33 \%$ ). Mr. Sarosi finds that the "checkerboard" cut (again, see figure 1) works best to minimize breakage during cutting.

Physical and Optical Properties. Since we might expect the physical and optical properties of tourmaline to vary with color, we arranged the data into three classes: pink (including red), yellowgreen, and multicolored stones. The properties for each of these groups are summarized in table 1. A desaturated "blend" of pleochroic colors was seen in some of the multicolored stones. All 13 stones on 
Figure 4. The multicolored tourmalines are fashioned as either a single color or as a mixture of colors in $a$ single stone. These four elbaite tourmalines, which range from 3.38-8.14 ct, were part of the study sample. Courtesy of Marc Sarosi; photo by Maha DeMaggio.
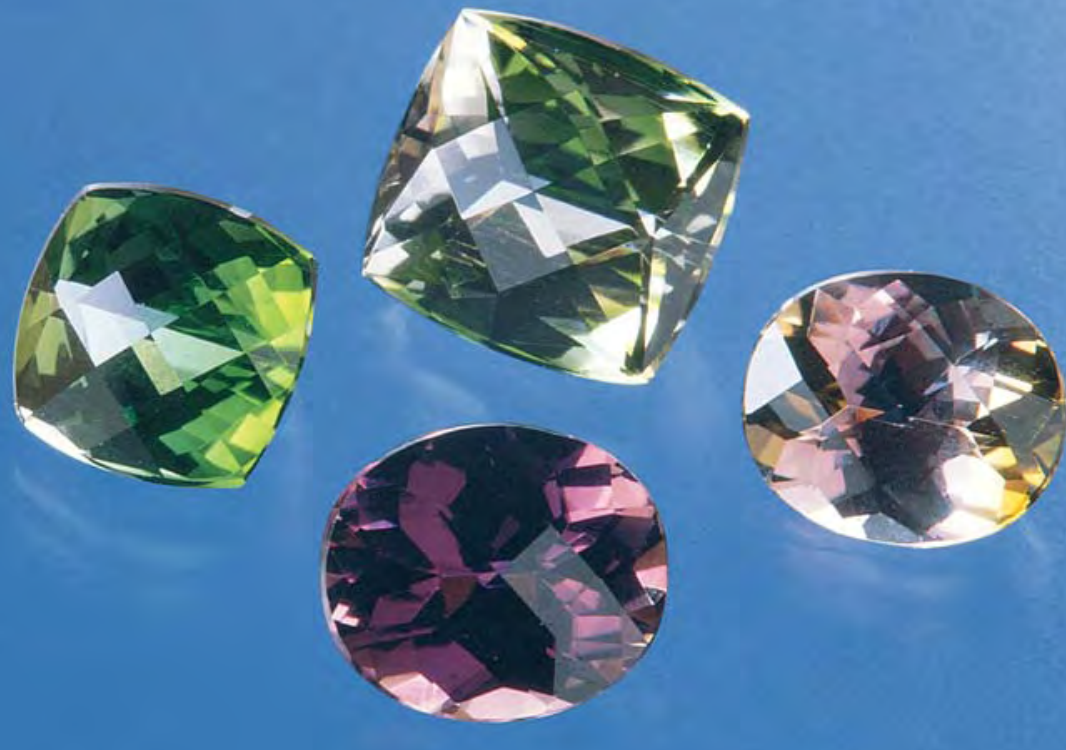

which refractive index readings were taken had R.I.'s in the range of $\mathrm{n}_{\varepsilon}=1.619-1.620$ and $\mathrm{n}_{\omega}=$ $1.637-1.639$, with birefringences of 0.018-0.020. None of the stones tested showed any reaction to UV radiation. These properties are not unusual for tourmalines of these colors.

Spectroscopy. The samples showed typical spectra for tourmalines of similar colors (again, see table 1).
Microscopy/Inclusions. The main inclusions seen with magnification were: "pinpoints" (very small minerals), growth tubes (figure 6) or needles, and fractures. All of these inclusions are common in tourmaline, regardless of its source, and there was no indication of possible included bismuth minerals (e.g., metallic bismuthinite or native bismuth, or high-relief near-colorless bismutite). Small opaque reddish orange spheres were noted in the ends of

TABLE 1. Gemological properties for various colors of Lundazi tourmaline.

\begin{tabular}{|c|c|c|c|}
\hline Property & Pink & Yellow-green & Multicolored \\
\hline Weight & $3.04-9.44 \mathrm{ct}$ & $4.75-11.48 \mathrm{ct}$ & $3.38-8.14 \mathrm{ct}$ \\
\hline Color & $\begin{array}{l}\text { Purplish pink to red-purple to } \\
\text { orangy red }\end{array}$ & Yellowish green to greenish yellow & Pink and yellowish green \\
\hline Pleochroism & $\begin{array}{l}\text { Purplish red to red-orangy red } \\
\text { to yellow }\end{array}$ & $\begin{array}{l}\text { Yellowish green to green-yellow to } \\
\text { green to green-brown }\end{array}$ & $\begin{array}{l}\text { Mixtures of the colors seen in } \\
\text { the pink and yellow-green } \\
\text { stones }\end{array}$ \\
\hline Optic character & Uniaxial & Uniaxial & Uniaxial \\
\hline Color-filter reaction & Gray-green & Slightly grayish green to green & Gray-green to grayish green \\
\hline R.I. $\left(n_{\varepsilon}\right)$ & $1.619-1.620$ & $1.619-1.620$ & 1.620 \\
\hline R.I. $\left(n_{\omega}\right)$ & $1.637-1.638$ & $1.638-1.639$ & 1.639 \\
\hline Birefringence & 0.018 & $0.018-0.020$ & 0.019 \\
\hline Specific gravity & $3.041-3.043$ & $3.040-3.049$ & $3.045-3.055$ \\
\hline $\begin{array}{l}\text { Reaction to long- } \\
\text { and short-wave UV }\end{array}$ & Inert & Inert & Inert \\
\hline Absorption spectrum & $\begin{array}{l}\text { Lines at } 451 \text { and } 458 \mathrm{~nm} \text {, weak } \\
\text { group of } 4 \text { or } 5 \text { lines to } 500 \mathrm{~nm} \text {; } \\
535 \mathrm{~nm} \text { line, } 490-540 \mathrm{~nm} \text { band, } \\
\text { absorption below } 415 \mathrm{~nm}\end{array}$ & $\begin{array}{l}\text { One stone: lines at } 460 \text { and } 500 \mathrm{~nm} \text {, } \\
\text { general absorption above } 640 \mathrm{~nm} \text {. } \\
\text { The rest: weak general absorption } \\
\text { below } 500 \mathrm{~nm} \text {, faint to weak diffuse } \\
500 \mathrm{~nm} \text { line }\end{array}$ & $\begin{array}{l}\text { Mixture of pink and yellow- } \\
\text { green spectra }\end{array}$ \\
\hline Inclusions & $\begin{array}{l}\text { "Pinpoints" of tiny colorless } \\
\text { crystals, parallel growth tubes, } \\
\text { one small transparent plate; } \\
\text { filled growth tube }\end{array}$ & $\begin{array}{l}\text { Clean, or scattered "pinpoints" only; } \\
\text { "pinpoints" lying in growth planes; thin } \\
\text { growth tubes near perimeter of stone }\end{array}$ & $\begin{array}{l}\text { Curved or planar clouds of } \\
\text { "pinpoints"; growth tubes, } \\
\text { primarily in green areas; filled } \\
\text { growth tubes }\end{array}$ \\
\hline Growth structures & Minimal to angular & Wavy and/or angular & Straight, wavy, and/or angular \\
\hline
\end{tabular}


growth tubes in four samples.

The prominent growth features we identified were growth bands--sharp boundaries between regions of slightly different refractive index, similar to the graining seen in diamonds. These bands were straight, angular, or wavy. Angular growth bands were seen in pink, yellow-green, and multicolored stones; wavy growth bands in combination with angular growth bands were seen in yellow-green and multicolored stones; and straight growth bands in combination with angular growth bands were seen in multicolored stones. In one pink stone, we saw only minimal growth banding. The growth bands were pronounced (eye-visible) in nearly all stones; however, no strain was obvious in any stone when viewed between crossed polarizers.

\section{CHEMICAL ANALYSIS}

EDXRF. We performed EDXRF analyses on six of the faceted tourmalines: two pink, one yellowgreen, two multicolored (analyzed without regard to color orientation), and one pink-and-yellowish green bicolor in which both color regions could be separately examined. Selected-energy-region EDXRF analyses for bismuth were performed on eight additional stones-three pink, two yellowgreen, and three multicolored. These analyses could be roughly quantified on the basis of the microprobe results (see below). We found major amounts

Figure 5. The multicolored nature of the fashioned stones comes from the cutter's incorporation of the different color zones in the original tourmaline rough. Attractively mixed in the face-up view of this $5.87 \mathrm{ct}$ Lundazi tourmaline, the color zones are clearly evident in the side view of a $4.94 \mathrm{ct}$ Lundazi stone. Photo by Maha DeMaggio.

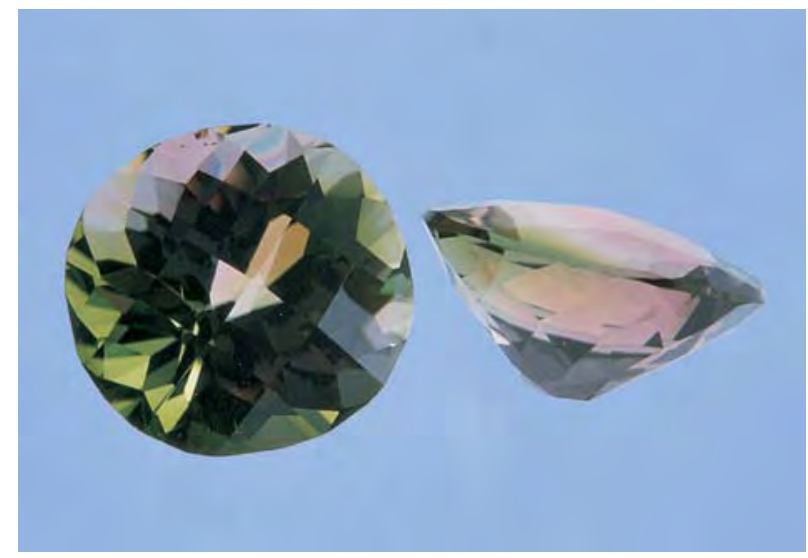

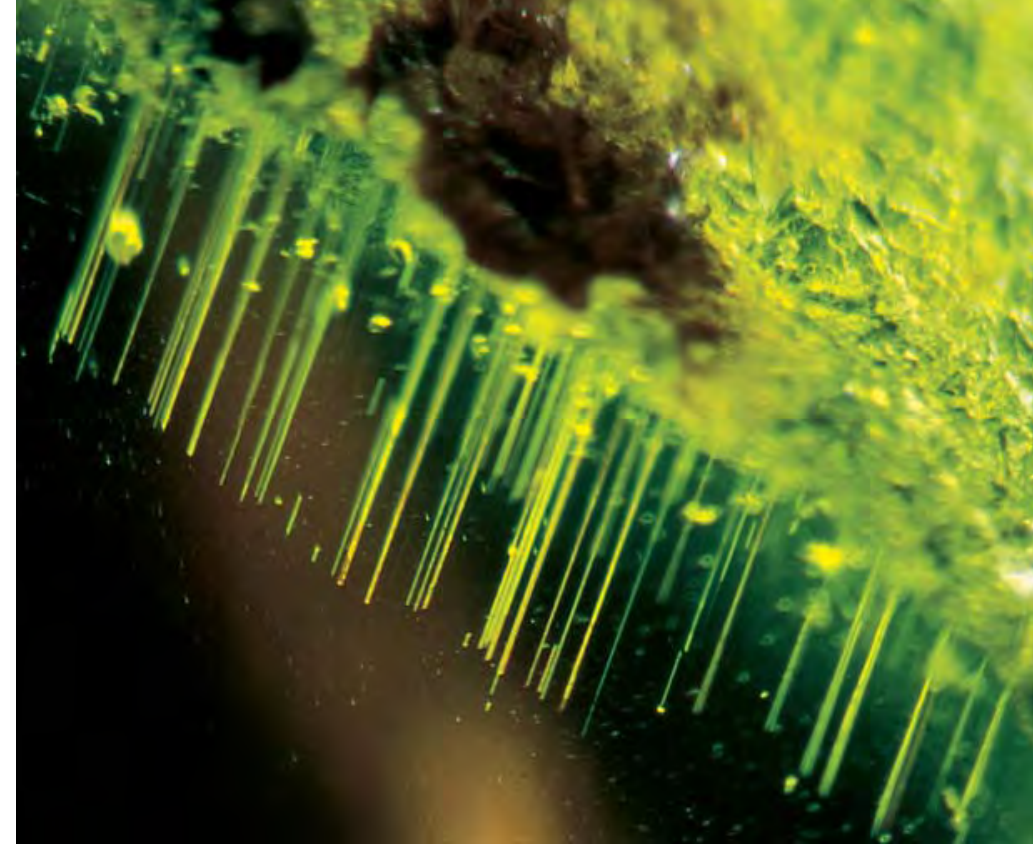

Figure 6. Some of the growth tubes in the green rind of this $12.02 \mathrm{ct}$ multicolored tourmaline nodule are partially filled with an orange material. Photomicrograph by John I. Koivula; magnified 20x.

(greater than 1 wt.\% oxide) of $\mathrm{Al}$ and $\mathrm{Si}$, and minor (greater than 0.1 wt.\% oxide) $\mathrm{Ca}$ and $\mathrm{Mn}$. The $\mathrm{Fe}$ content could be classified as major, minor, or trace (less than $0.1 \mathrm{wt} . \%$ oxide) in these stones, depending on color: The amount of absorption due to $\mathrm{Fe}$ is appreciably greater in the spectra of yellow-green stones (or regions) than in those of pink stones (or regions). Bismuth occurred at minor to trace levels. Trace amounts of $\mathrm{Cu}, \mathrm{Zn}, \mathrm{Ga}$, and $\mathrm{Ge}$ were found in all the EDXRF spectra. Ti was seen in the yellowgreen region of one multicolored stone and in another multicolored stone at the trace level. $\mathrm{Pb}$ was detected in one multicolored stone.

Each of the eight spectra taken using conditions to detect only Bi revealed relatively high amounts of that element (i.e., at the minor-element level), regardless of the color of the material. Raw counts in the EDXRF analyses suggest that more Bi is present in the early-forming pink zones (i.e., the cores of the multicolored nodules) than in the later-forming yellow-green rinds.

Electron Microprobe. Three samples were examined in more detail using an electron microprobe (the two cut stones shown in figure 1 and the multicolored nodule shown in figure 7); the results are given in table 2. The compositions indicate that these tourmalines are all elbaite, the sodium-, lithium-, and aluminum-rich species in the tourmaline mineral group. As with the EDXRF analyses, the green rind of the tourmaline nodule showed less bismuth 
than the pink core. The most bismuth (0.49 wt.\%) was found in the pink stone.

\section{DISCUSSION}

The gemological properties of the Zambian tourmalines we studied are consistent with those of the tourmalines from the Lundazi area described by Thomas (1982). One reason for extensive past interest in Zambian tourmalines was the possibility that specimens from the Chipata area might have been the hypothetical manganese-rich species tsilaisite, although none proved to be so (see, e.g., Schmetzer and Bank, 1984a and b; Shigley et al., 1986). All the stones examined for the present study have low Mn contents.

The unusual feature of these elbaites is their high Bi contents. Traces of Bi are sometimes found in rocks crystallized from late-stage silicic melts (i.e., in granitic pegmatites: see, e.g., Mintser, 1979); in Zambia, a possible source for this element is the nearby gold deposits (Kamona, 1994). However, bismuth does not readily substitute for common elements in silicates (see, e.g., Kupč́k, 1972), so its presence in tourmaline is unexpected.

Figure 7. Microprobe analyses across the primary color zones-pink and green-in this Lundazi tourmaline nodule showed higher Bi contents in the pink core. Courtesy of Marc Sarosi; photo (C) GIA and Tino Hammid.

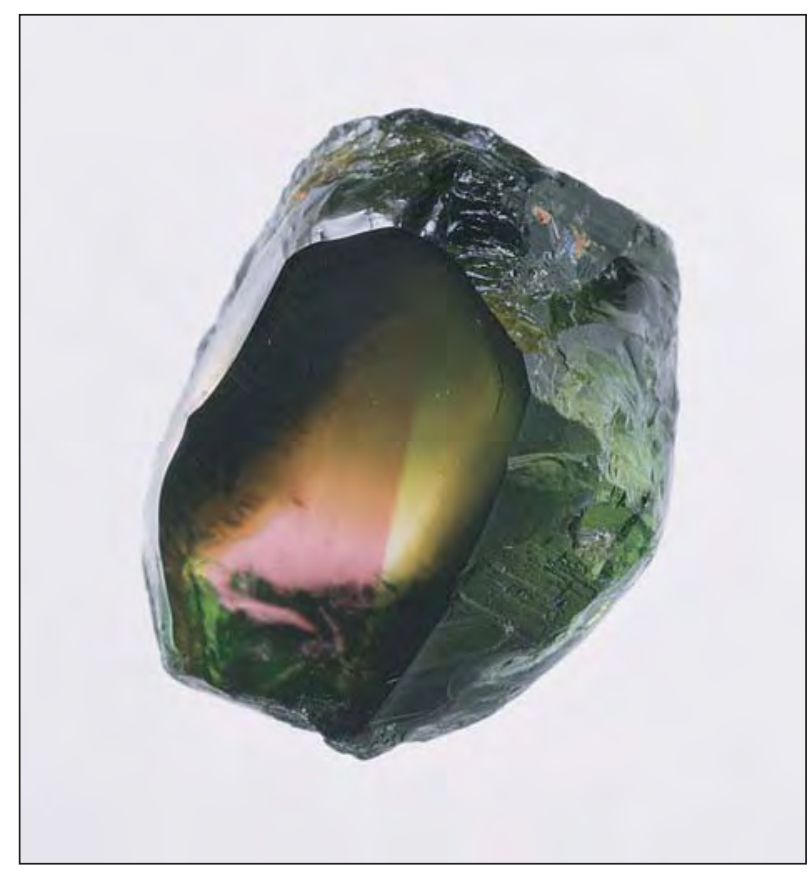

TABLE 2. Electron microprobe data for three Lundazi tourmalines.

\begin{tabular}{|c|c|c|c|c|}
\hline \multirow[b]{2}{*}{$\begin{array}{l}\text { Oxide } \\
\text { (wt.\%) }\end{array}$} & \multirow[b]{2}{*}{$\begin{array}{c}\text { Pink } \\
\text { (3 points) }\end{array}$} & \multirow[b]{2}{*}{$\begin{array}{l}\text { Yellow-green } \\
\text { (3 points) }\end{array}$} & \multicolumn{2}{|c|}{ Multicolored nodule } \\
\hline & & & $\begin{array}{l}\text { Green rind } \\
\text { (4 points) }\end{array}$ & $\begin{array}{l}\text { Pink core } \\
\text { (4 points) }\end{array}$ \\
\hline $\mathrm{SiO}_{2}$ & $38.00-38.50$ & $38.00-38.90$ & $38.00-39.10$ & $38.60-39.10$ \\
\hline $\mathrm{TiO}_{2}$ & nda & $0.03-0.05$ & $0.05-0.34$ & $\mathrm{nd}-0.02$ \\
\hline $\mathrm{Al}_{2} \mathrm{O}_{3}$ & $41.00-41.30$ & $39.20-40.60$ & $37.10-40.00$ & $41.30-41.90$ \\
\hline $\mathrm{V}_{2} \mathrm{O}_{3}$ & $\mathrm{nd}-0.01$ & $\mathrm{nd}-0.02$ & nd & nd \\
\hline $\mathrm{Cr}_{2} \mathrm{O}_{3}$ & $\mathrm{nd}-0.05$ & nd -0.12 & nd -0.09 & $\mathrm{nd}-0.12$ \\
\hline $\mathrm{Bi}_{2} \mathrm{O}_{3}$ & $0.34-0.49$ & $\mathrm{nd}-0.13$ & nd-0.02 & $0.16-0.25$ \\
\hline $\mathrm{MgO}$ & nd & $0.04-0.07$ & $0.21-0.61$ & nd \\
\hline $\mathrm{CaO}$ & $0.51-0.58$ & $0.51-1.07$ & $0.09-0.34$ & $0.38-0.47$ \\
\hline $\mathrm{MnO}$ & $0.18-0.26$ & $0.30-0.48$ & $0.36-0.91$ & $0.26-0.38$ \\
\hline $\mathrm{FeO}$ & nd -0.07 & $0.69-0.84$ & $1.70-4.19$ & $0.03-0.13$ \\
\hline $\mathrm{ZnO}$ & nd -0.02 & $0.01-0.03$ & nd -0.05 & nd \\
\hline $\mathrm{Na}_{2} \mathrm{O}$ & $1.66-1.74$ & $1.74-1.83$ & $2.03-2.49$ & $1.70-1.82$ \\
\hline $\mathrm{K}_{2} \mathrm{O}$ & $\mathrm{nd}-0.01$ & $0.01-0.02$ & nd -0.02 & nd -0.01 \\
\hline $\mathrm{P}_{2} \mathrm{O}_{5}$ & $\mathrm{nd}-0.01$ & nd & $\mathrm{nd}-0.01$ & $\mathrm{nd}-0.03$ \\
\hline $\mathrm{Li}_{2} \mathrm{O}^{\mathrm{b}}$ & $2.14-2.19$ & $2.04-2.31$ & $1.80-2.16$ & $2.11-2.27$ \\
\hline $\mathrm{F}$ & $0.01-1.12$ & $0.88-1.00$ & $0.95-1.12$ & $0.85-1.07$ \\
\hline $\mathrm{B}_{2} \mathrm{O}_{3}{ }^{\mathrm{C}}$ & $11.03-11.13$ & $11.03-11.09$ & $10.87-11.19$ & $11.18-11.25$ \\
\hline $\mathrm{H}_{2} \mathrm{OC}$ & $3.30-3.84$ & 3.35-3.39 & $3.29-3.40$ & $3.37-3.46$ \\
\hline$-0=F$ & $(-0.47)-n d$ & $(-0.42)-(-0.37)$ & $(-0.47)-(-0.40)$ & $(-0.45)-(-0.36)$ \\
\hline Total & $\overline{99.01-99.84}$ & $\overline{99.39-100.09}$ & $\overline{100.06-101.15}$ & $\overline{100.27-101.39}$ \\
\hline
\end{tabular}

and=none detected.

bDetermined by assuming there are $3 Y$ cations per formula unit, among them Ti, Al, V, Cr, Mg, Mn, Fe, Zn, and Li (see Burns et al., 1994). cDetermined from tourmaline stoichiometry: 3 B per formula unit, $4(\mathrm{OH}+\mathrm{F})$ per formula unit.

Examples of Bi-bearing tourmaline are relatively uncommon. In an exhaustive literature search, Dietrich (1985) noted trace amounts of Bi in draviteuvite and schorl tourmalines, but not in elbaites. Peretyazhko et al. (1991) described rubellites (elbaites) from miarolitic granitic pegmatites in the Malkhan Range in Central Transbaikalia, Russia, that contained both $\mathrm{Bi}$ (up to 0.55 wt. $\% \mathrm{Bi}_{2} \mathrm{O}_{3}$ ) and lead. The elbaites from São José da Batalha, Paraíba, Brazil, are best known for their copper contents, but they also contain up to 0.83 wt. $\% \mathrm{Bi}_{2} \mathrm{O}_{3}$ (on the basis of microprobe analyses by Fritsch et al., 1990; Henn et al., 1990; and Rossman et al., 1991). In addition, according to unpublished microprobe data, a color-change tourmaline from East Africa (described by Koivula and Kammerling, 1991) contained trace amounts of $\mathrm{Bi}$.

One reason for the paucity of information on bismuth in tourmaline is that most modern analyses are performed with the electron microprobe, which has a relatively high detection limit (e.g., 0.17 wt. $\% \mathrm{Bi}_{2} \mathrm{O}_{3}$ in our analyses; however, EDXRF is considerably more sensitive for Bi. Further, unless bismuth is looked for in microprobe analyses, it will 
not in general be found. We would not be surprised if tourmalines from other localities are also found to contain significant amounts of bismuth.

It is not apparent what effect, if any, bismuth has on the gemological properties of tourmaline. Bismuth is not a chromophore (see, e.g., Kupćík, 1972). As a heavy element, its presence should increase both specific gravity and refractive index (see, e.g., Bloss et al., 1983), but neither of these properties appears to have been affected at the concentration levels noted in our samples.

\section{CONCLUSION}

Significant amounts of tourmaline from a new alluvial deposit in the Lundazi area of Zambia are now available. These attractive tourmalines are notable for their chemical composition (Bi-bearing elbaite) as well as for the unusual "mixed-color" appearance of the faceted stones, a consequence of the durability problems inherent in the rough. About 10,000 ct of faceted stones are now available, and tons of lower-quality material have been mined.

Bismuth is not usually present at detectable levels in gem tourmaline. In the Lundazi stones, more Bi was measured in the pink cores than in the green rinds, and individual analyses give concentrations of up to $0.49 \mathrm{wt} . \% \mathrm{Bi}_{2} \mathrm{O}_{3}$. Nevertheless, the presence of $\mathrm{Bi}$ in these tourmalines does not appear to influence their gemological properties. The most distinctive property of these stones is the growth zoning; otherwise, the gemological properties are consistent with those recorded for elbaites of similar colors from other localities.

Acknowledgments: The authors thank Marc Sarosi of Marc Sarosi Co., Los Angeles, for making this material available to us, and for responding so willingly to our repeated queries. Dr. Frank Hawthorne and Julie Selway of the University of Manitoba, Canada, provided electron microprobe analyses. Staff gemologist Dino DeGhionno, GIA Gem Trade Laboratory, Carlsbad, confirmed the gemological observations; and Sam Muhlmeister, GIA Research, Carlsbad, aided in the interpretation of the EDXRF spectra. Dr. Eugene Foord, of the U.S. Geological Survey, brought the Malkhan material to our attention, and provided translation of some of the relevant Russian results.

\section{REFERENCES}

Bank H. (1982) Turmaline diverser Grün- und Rottöne aus Sambia. Zeitschrift der Deutschen Gemmologischen Gesellschaft, Vol. 31, No. 1/2, pp. 91-92.

Bloss F.D., Gunter M., Shu C.S., Wolfe H.E. (1983) The Gladstone-Dale constants: A new approach. Canadian Mineralogist, Vol. 21, No. 1, pp. 93-99.

Burns P.C., MacDonald D.J., Hawthorne F.C. (1994) The crystal chemistry of manganese-bearing elbaite. Canadian Mineralogist, Vol. 32, No. 1, pp. 31-41.

Dietrich R.V. (1985) The Tourmaline Group. New York, Van Nostrand Reinhold Co., 300 pp.

Fritsch E., Shigley J.E., Rossman G.R., Mercer M.E., Muhlmeister S.M., Moon M. (1990) Gem-quality cuprian-elbaite tourmalines from São José da Batalha, Paraíba, Brazil. Gems ↔) Gemology, Vol. 26, No. 3, pp. 186-205.

Henn U., Bank H., Bank F.H. (1990) Transparent bright blue Cubearing tourmalines from Paraiba, Brazil. Mineralogical Magazine, Vol. 54, pp. 553-557.

Kamona A.F. (1994) Mineralization types in the Mozambique Belt of eastern Zambia. Journal of African Earth Sciences, Vol. 19, No. 3, pp. 237-243.

Koivula J.I. (1985) Gem news: Tucson 1985. Gems «) Gemology, Vol. 21, No. 1, p. 60.

Koivula J.I., Fryer C.W. (1985) Interesting red tourmaline from Zambia. Gems « Gemology, Vol. 21, No. 1, pp. 40-41.

Koivula J.I., Kammerling R.C. (1991) Gem News: Tourmaline

with unusual "color change." Gems \&) Gemology, Vol. 27 No. 3, pp. 184-185.

Kupčík V. (1972) Bismuth: Crystal chemistry. In K. H. Wedepohl, Ed., Handbook of Geochemistry, Vol. II/1, Springer-Verlag, Berlin, pp. 83-B-1-83-M-1, 83-O-1.

Mintser E.F. (1979) The geochemical properties of the behavior of bismuth in hypogenic processes. In E.E. Angino and D.T. Long, Eds., Benchmark Papers in Geology, Vol. 49: Geochemistry of Bismuth, Dowden, Hutchinson \& Ross, Stroudsburg, PA, pp. 268-327.

Peretyazhko I.S., Zagorskiy V.Ye., Bobrov Yu.D. (1991) First find of bismuth- and lead-rich tourmaline. Doklady Akademii Nauk USSR, Earth Sciences Section, Vol. 307, No. 1-6, pp. 175-179 [In Russian].

Rossman G.R., Fritsch E., Shigley J.E. (1991) Origin of color in cuprian elbaite from São José da Batalha, Paraíba, Brazil. American Mineralogist, Vol. 76, pp. 1479-1484.

Schmetzer K., Bank H. (1984a) Crystal chemistry of tsilaisite (manganese tourmaline) from Zambia. Neues Jahrbuch für Mineralogie Monatshefte, No. 2, pp. 61-69.

Schmetzer K., Bank H. (1984b) Intensive yellow tsilaisite (manganese tourmaline) of gem quality from Zambia. Journal of Gemmology, Vol. 19, No. 3, pp. 218-223.

Shigley J.E., Kane R.E., Manson D.V. (1986) A notable Mn-rich gem elbaite tourmaline and its relationship to "tsilaisite." American Mineralogist, Vol. 71, pp. 1214-1216.

Thomas A.E. (1982) Zambian tourmaline. Journal of Gemmology, Vol. 18, No. 1, pp. 4-6. 